\title{
PERGESERAN NILAI PILAR DEMOKRASI DALAM KERANGKA OTONOMI DAERAH
}

\author{
Saeful Kholik \\ Universitas Wiralodra
}

Email : saefulkholik21@gmailcom

\begin{abstract}
In a government organization, the expertise of the law making is most accumulated. It enables the law making process to be easily done by law the enforcers. This fact causes the role of government to be central. It also lead to an access of government organizations to become very powerful over the functions of organizations that exist within and outside the government. Therefore, to avoid concentration of power in the hands of government organizations, the idea arises to hold a separation and division of powers. The emergence of a constitutional idea of a rule of law basically changes the power of the government. It makes their existence is not too dominant to see the Indonesian government system recognizing regional government and regional autonomy which are basically capable of impacting in the system of pillars of the democratic legal order. The shift of legislative and executive power within the framework of regional autonomy has indeed occurred with the dynamics of a structurally structured and infrastructural political life. It has an authority over each of the institution's committees. It acts an important function and even considered as the main function of the parliamentary institution. Important function is the legislative institution that is the institution legislators or institutions that determine the making of the law.
\end{abstract}

Keywords: Regional Autonomy, Legislative Power, Lawmaking.

\section{PENDAHULUAN}

Hukum dalam arti luas meliputi keseluruhan aturan normative yang mengatur dan menjadi sebuah pedoman prilaku dalam kehidupan bermasyarakat dan bernegara yang didukung oleh sitem sanksi tersebut terhadap setiap sebuah penyimpangan terhadapnya. Bentuk bentuk aturan normative tersebut tumbuh sendiri dalam aturan masarakat dan bernegara ataupun sengaja dibuat menurut prosedur-prosedur yang ditentukan dalam system organisasi kekuasaaan dalam bermasyarakat yang sangatlah bersangkutan.

Kompleksitas terhadap kemajuan masyarakat dan kehidupan memberikan sebuah output yang mampu menkankan kepada perkembangan sebuah aturan dan pola-pola prilaku dalam kehidupan bersamyarakat, Tentunya dalam sebuah keteraturan ini kemudian melahirkan sebuah organisasi yang menunjukan sebuah perkembangan menjadi system organisasi organizational imperative, Majunya sebuah masyarakat terhadap majunya 
perkembangan kecenderungan masyrakatnya untuk mengikatkan diri kepada system keorganisasian dan aturan yang terkait.

Dalam system pengorganisasian yang teratur itu pada giliranya tercipta pula mekanisme yang tersendiri berkenaan dengan proses pembuatan hukum, penerapan hukum, dan peradilan terahdap penyimpangan-pemyimpangan hukum dalam masyrakat yang semakin dan maju terhadap pengorganisasian tersebut.

Dengan demikian bukan saja dianggap setiap masyarakat seperti ada hukum seperti apa yang sudah dikatakan dalam pakar cesaero akan tetapi perlu dingat bahwa setiap tahapan perkembangan masyarakat yang makin kompleks dan maju yang akan menyebabkan kompleksitas perkembangan hukum juga makin meningkat baik dari segi kuantitas mauoun segi kualitas.

Pemerintah pada pokoknya merupakan sebuah produsen hukum terbesar sepanjang sejarah. Alasan sederhana adalah pemerintah dapatlah menguasai informasi yang paling banyak dan memiliki akses paling luas dan besar dalam lingkunannya untuk dapatlah memperoleh sebuah informasi yang dibutuhkan dalam sebuah proses pembuatan hukum dan prakteknyalah harus sesuai dengan yang di idekan, pemerintah juga yang paling tau dan memahami untuk siapa berapa dan kapan dimana dan bagaimana hukum itu akan dibuat.

Dalam sebuah organisasi pemerintah keahlian dan tenaga ahli paling banyak terkumpul yang memungkinkan proses pembuatan hukum itulah dapat dengan mudah dikerjakan oleh para penegak hukum, kenyataan ini mengakibatkan peran pemerintah menjadi sentral dan dapatkah pula menimbulkan sebuah akses organisasi pemerintah menjadi sangatkah berkuasa diatas fungsi-fungsi oraganisasi yang ada didalam maupun diluar pemerintah, Oleh karena itu untuk menghindari pemusatan kekuasaan ditangan organisasi pemerintah munculah sebuah ide untuk mengadakan pemisahan kekuasaan dan pembagian kekuasaan, Munculnya sebuah ide konstituasional gagasan Negara hukum pada dasarknya berubah membatasi kekuasaan pemerintah agar tidak terlalu dominan melihat system pemerintahan indoensia mengakui pemerintahan daerah dan otonomi daerah yang pada dasarnya mampu berdampak pada system pilar-pilar tatanan hukum secara demokrasi ${ }^{1}$.

Impelentasinya banyak system pemerintahan dan demokrasi dalam era otonomi daerah mengalami beberapa kendala yang salah satunya dengan menagkui system

\footnotetext{
1 Soehino, Hukum Tata Negara, Liberty, Yogyakarta, 1991, hlm. 28.
} 
pemerintahan otonomi daearah yang memberikan pembagian kekuasaan dan pergeseran kekuasaan yang tidak terbatas inilah menjadi sebuah garis kordinasi yang kurang baik hal ini pula tidak terlepas dari sebuah system tatanan politik.

Dari urian diatas penulis menemukan sebuah nilai nilai pergeseran yang sangat berbuah oleh karena itu penulis merumuskan penelitian dengan judul: PERGESERAN NILAI PILAR DEMOKRASI DALAM KERANGKA OTONOMI DAERAH.

Berdasarkan latar belakang permasalahan diatas maka penulis mengangkat permasalahan yang akan di teliti sebagai berikut:

1. Bagaimanakah pergeseran kekuasaan legislative dan eksekutif dalam kerangka otonomi daerah?

2. Bagimanakah kelembagaan Negara sebagai supratruktur politik dalam kerangka system otonomi daerah?

\section{METODE}

Penelitian ini akan dikaji dan dijelaskan serta dianalisa teori hukum yang bersifat umum, peraturan perundang-undangan dan peraturan lainnya yang berlaku dan berhubungan dengan pergeseran pilar-pilar demokrasi. Penelitian ini adalah penelitian hukum yuridis normatif yaitu penelitian atas peraturan perundang-undangan baik ditinjau dari sudut hirarki perundang-undangan (vertikal), maupun hubungan harmoni diantara perundang-undangan (horizontal).

\section{HASIL DAN PEMBAHASAN}

\subsection{Bagaimanakah Pergeseran Kekuasaan Legislatif Dan Eksekutif Dalam Kerangka Otonomi Daerah}

Permasalahan yang paling utama dan pokok dalam pergeseran nilai Ilmu Hukum Tata Negara dan Politik sepanjang sejarah terdapat dalam sebuah mekanisme hubungan antara Negara dan rakyat dalam suatu Negara dan bangsa, Kepentingan Negara dan bangsa bisaanya diwakili oleh pemerintah sedangkan kepentingan rakyat yang sifatnya diinstitusionalkan atau terlembagakan melalui sebuah parlemen baik parlemen yang bersifat Unikameral (Monokameral) ada juga yang bersfiat bicameral dan bahkan ada pula parlemen yang bersifat trikameral seperti Negara china namun tak menutupi pula seperti negara 
Indonesia yang memiliki karakter tersendiri dalam pemerintahan mengakui adanya otonomi daerah yang memang sering sekali pergeseran ini sangatlah terjadi.

Pentingnya hubungan di antara kedua institusi pemerintah dan parlemen tersebut berkaitan dengan sebuah penilaian menegnai sebuah derajat keterlibatan rakyat dalam sebuah kekuasaaan negeara sebagai ukuran utama dalam pemahaman mengenai sebuah nilai-nilai demokrasi. Salah satu fungsi penting dan bahkan dianggap utama dari lemabaga perlemen adalah fungsi penting adalah lembaga legislatif yaitu lembaga pembuat undangundang ataupun lembaga yang menentukan pembuatan hukum tersebut. Didalamnya yang terkait hak dan kewajiban inisitaif guna merancang dan merumuskan racangangan peraturan perundang-undangan serta membahas dan mengadakan amandemen dan modifikasi terhadap rancangan undang-undang, serta pengawasan pelaksanaan undang-undang itu kelak stelah dibubarkan.

Dalam mengamati berbagai masalah ketenagaraan sering kali seorang mengabaikan pertimbangan-pertimbangan historis yang berkaitan erat dengan dinamika perubahan yang seharusnya diperhatikan. Hal demikianlah yang membuat para praktisi hukum membuat sebuah kebijakan dalam penanggulanga pergeseran tersebut ${ }^{2}$.

Akibat dari hal tersebut yang dipandang pemerintahan awam mengenai masalahmasalah ketenagaraan, khususnya dalam memberikan penelian terhadap penilaian terhadap peran pemerintahan Indonesia, Akibatnya setiap kali dinamika hubungan antara Dewan Perwakilan Rakyat dan pemerintah pradigma dalam pandangan masyarakat dan hanya perwakilan yang tidak dapat berjalan dengan baik dan membingungkan hal ini didasarkan oleh tumpang tindihnya peraturan dan saling mengambil alih kewenangan satu sama lainnya yang mendeskripsikan bahwa DPR tidaklah berkedudukan dengan baik dan benar sesuai dengan amanat Undang-Undang Dasar 1945.

Salah satu contoh pergeseran nilai terlihat dari sebuah pemerintahan yang dari system parlemen kepada sistem pemerintahan yang memang mengalami sebuah perubahan yang sangat mendasar dalam perkembanganya menegnai peran parlemen hal ini bisa dilihat dari sebuah kecenderungan tercadinya sebuah pergeseran peran dari eksekutif ke legislatif kecenderungan yang terjadi sekarang ini justru terjadi dari legislatif ke eksekutif seperti yang dikatakan oleh Ivo D. Duchacek.

\footnotetext{
2 Suny Ismail. Pergeseran Kekuasaaan Eksekutif, Calindra, Jakarta, 1965, hlm. 39.
} 
"National legislators now seem to have lost much of what they gained in wrenching the law-initating and law-writing monopoly from raoyal and aristocratic excekutives. Law making is now, at best, a shared power. The executive in most systems has become to dominant source of legislation initiative and it retains the traditionally recognized role of excecuitng laws" ${ }^{3}$.

Para anggota parlemen nasional ternyata banyak kehilangan dibandingakan dengan apa yang mereka miliki sejak lama dalam monopoli inisiatif pembuatan dan penyusunan Undang-Undang dari para ekeskutif pemimpin yang memiliki sebuah kewenangan tersendiri, Pembuatan undang-undang saat ini sudah menjadi sebuah pekerjaan bersama antara para legislator dan para eksekutif dalam semua system yang sekarang ini pihak eksekutif telah menjadi cabang kekuasaan yang lebih dominan pengaruhnya dan peranannya sebagai sumber inisiatif pembuatan undang-undang hal inilah sering sekali terjadi berbenturan dengan garis kordinasi satau sama lain di karenakan mempunya kewenangan satu sama lainya yang tidak sedikit pula dengan bertentanangan satu sama lain.

\subsection{Bagaimanakah Kelembagaan Negara Sebagai Supratruktur Politik Dalam Kerangka System Otonomi Daerah}

Untuk memahami pengertian lembaga atau organ Negara secara lebih dalam, kita dapat mendekatinya dari pandangan Hans Kelsen mengenai The concept of the state organ dalam bukunya General Theory of law and state. Hans Kelsen menguraikan bahwa whoever fulfills a function determined by the legal order is an organ. Siapa saja yang menjalankan suatu fungsi yang ditentukan oleh suatu tata hokum (legal order) adalah suatu organ.

Artinya, organ Negara itu tidak selalu berbentuk organik. Disamping organ yang berbentuk organik, lebih luas lagi, setiap jabatan yang ditentukan oleh hokum dapat pula disebut organ, asalkan fungsi-fungsinya itu bersifat menciptakan norma (norm applying). These functions, be they of a norm creating or of a norm applying character, are all ultimately aimed at the execution of a legal sanction.

Menurut Kelsen, parlemen yang menetapkan undang-undang dan warga Negara yang memilih para wakilnya melalui pemilihan umum sama-sama merupakan organ Negara dalam arti luas. Demikian pula hakim yang mengadili dan menghukum penajahat dan terpidana yang menjalankan hukuman tesebut di lembaga permasyarakatan, adalah juga merupakan organ Negara. Pendek kata, dalam pengertian yang luas ini, organ Negara itu

\footnotetext{
3 Ivo D. Duchaecek, Power Maps, Comperative Politics Of Constitions American Bibilographical Center,
} Santa Barbara, California, Oxfrod, 1973, hlm. 321. 
identik dengan individu yang menjalankan fungsi atau jabatan tertentu dalam konteks kegiatan bernegara. Inilah yang disebut sebagai jabatan publik atau jabatan umum (public officies) dan pejabat publik atau pejabat umum (public officials).

Dikatakan oleh Hans Kelsen, An organ, in this sense, is an individual fulfilling a specific function. Kualitas individu itu sebagai organ Negara ditentukan oleh fungsinya. He is an organ because and in so far as he performs a law creating or law applying functions. Individu tersebut dapat disebut sebagai organ Negara, karena ia menjalankan fungsi yang menciptakan hokum (law creating functions) atau fungsi yang menerapkan hokum (law applying functions).

Disamping pengertian luas itu, Hans Kelsen juga menguraikan adanya pengertian organ Negara dalam arti yang sempit, yaitu pengertian organ dalam arti materill. Individu dikatakan organ Negara hanya apabila ia secara pribadi memiliki kedudukan hukum yang tertentu (he personally has a specific legal position). Suatu transaksi hukum perdata, misalnya, kontrak, adalah merupakan tindakan atau perbuatan yang menciptakan hukum seperti halnya suatu putusan pengadilan ${ }^{4}$.

Lembaga Negara terkadang disebut dengan istilah lembaga pemerintahan, lembaga pemerintahan nondepartemen, atau lembaga Negara saja ada yang dibentuk berdasarkan atau karena diberi kekuasaan oleh UUD, ada pula yang dibentuk dan mendapatkan kekuasaanya dari Undang-undang, dan bahkan ada pula yang hanya dibentuk berdasarkan keputusan presiden. Hierarki atau ranking kedudukannya tentu saja tergantung pada derajat pengaturnya menurut peraturan perundang-undangan yang berlaku.

Lembaga Negara yang diatur dan dibentuk oleh UUD merupakan organ konstitusi, sedangkan yang dibentuk berdasarkan undang-undang merupakan organ undang-undang, sementara yang hanya dibentuk karena keputusan presiden tentunya lebih rendah lagi tingkatannya dan derajat perlakuan hukum terhadap pejabat yang duduk didalam nya. Demikian pula jika lembaga dimaksud dibentuk dan diberi kekuasaan berdasarkan peraturan daerah, tentu lebih rendah lagi tingkatannya.

Dalam setiap pembicaraan mengenai organisasi Negara, ada dua unsur pokok yang saling berkaitan, yaitu organ dan functie. Organ adalah bentuk atau wadahnya, sedangkan functie adalah isinya; organ adalah status bentuknya (Inggris: from, Jerman: vorm)

\footnotetext{
${ }^{4}$ Kelsen, Hans. General Theory of Law And Sate, Harvad Universty, Press, Cambridge, hlm. 50.
} 
sedangkan functie adalah gerakan wadah itu sesuai maksud pembentukannya. Dalam naskah Undang-undang Dasar Negara Republik Indonesia Tahun 1945, organ-organ yang dimaksud, ada yang disebut secara eksplisit namanya, dan ada pula yang disebut eksplisit hanya fungsinya. Ada pula lembaga atau organ yang disebut bahwa baik namanya maupun fungsi atau kewenangannya akan diatur dengan peraturan yang lebih rendah ${ }^{5}$.

Jika dikaitkan dengan hal tersebut di atas, maka dapat dikemukakan bahwa dalam UUD 1945, terdapat tidak kurang dari 34 organ yang disebut keberadaanya dalam UUD 1945. Ke-34 organ atau lembaga tersebut adalah berikut ini:

a. Majelis Permusyawahan Rakyat (MPR) diatur dalam bab III UUD 1945 yang juga diberi judul "majelis permusyawahan rakyat". Bab III ini berisi dua pasal, yaitu pasal 2 yang terdiri atas tiga ayat, pasal 3 juga terdiri atas tiga ayat

b. Presiden yang diatur keberadaany dalam bab III UUD 1945, di mulai dari pasal 4 ayat (1) dalam pengaturan mengenai kekuasaan pemerintahan Negara berisi 17 pasal.

c. Wakil Presiden yang kebradaan nya diatur dalam pasal 4 yaitu pada ayat (2) UUD 1945. Pasal 4 ayat (2) UUD 1945 itu menegaskan, Dalam melakukan kewajibannya, Presiden dibantu oleh satu orang wakil presiden.

d. Mentri dan kementrian Negara diatur tersendiri dalam Bab V UUD 1945, yaitu pada pasal 17 ayat (1), (2), dan ayat (3).

e. Mentri Luar Negeri sebagai mentri triumpirat yang oleh pasal 8 ayat (3) UUD 1945, yaitu bersama-sama Dengan Mentri Dalam Negeri dan Mentri Pertahanan sebagai pelaksana tugas kepresidenan apabila terdapat kekosongan dalam waktu yang bersamaan dalam jabatan Presiden dan Wakil Presiden.

f. Menteri Dalam Negeri sebagai triumpirat bersama-sama dengan mentri luar negri dan mentri pertahanan menurut pasal 8 ayat (3) UUD 1945.

g. Menteri pertahanan yang bersama-sama dengan Menteri Dalam Negeri ditentukan sebagai menteri triumpirat menurut pasal 8 ayat (3) UUD 1945. Ketiganya perlu disebut secara sendiri-sendiri, karena dapat saja terjadi konflik atau sengketa kewanangan konstitusional di antara sesame mereka, atau antara mereka dengan menteri lain atau lembaga Negara lainnya.

\footnotetext{
5 Huntington, Samuel.P, Gelombang Demokrasi Ketiga, Pustaka Utama Grafiti, Jakarta, hlm. 77.
} 
h. Dewan Pertimbangan Presiden yang diatur dalam pasal 16 Bab III tentang kekuasaan Pemerintahaan Negara yang berbunyi, Presiden membentuk suatu dewan pertimbsngsn yang bertugas memberikan nasihat dan pertimbangan kepada Presiden, yang selanjutnya diatur dalam undang-undang.

i. Duta seperti diatur dalam pasal 13 ayat (1) dan ayat (2).

j. Konsul seperti yang diatur dalam Pasal 13 ayat (1).

k. Pemerintahan Daerah Provinsi sebagaimana dimaksud oleh pasal 18 ayat (2), (3), (5), (6), dan ayat (7) UUD 1945.

1. Gubernur Kepala Pemerintahan Daerah seperti yang diatur dalam pasal 18 ayat (4) UUD 1945.

m. Dewan Perwakilan Rakyat Daerah Provinsi, seperti yang diatur dalam pasal 18 ayat (3) UUD 1945.

n. Pemerintah Daerah Kabupaten sebagaimana dimaksud oleh pasal 18 ayat (2), (3), (5), (6), dan ayat (7) UUD 1945.

o. Bupati Kepala Pemerintah Daerah Kabupaten seperti diatur dalam pasal 18 ayat (4) UUD 1945.

p. Dewan Perwakilan Rakyat Daerah Kabbupaten seperti yang diatur dalam pasal 18 ayat (3) UUD 1945.

q. Pemerintahan Daerah Kota sebagaimana dimaksud oleh pasal 18 ayat (2), (3), (5), (6) dan ayat (7) UUD 1945.

r. Walikota Kepala Pemerintah Daerah Kota seperti yang diatur dalam pasal 18 ayat (4) UUD 1945

s. Dewan Perwalikan Rakyat Daerah Kota seperti yang diatur oleh pasal 18 ayat (3) UUD 1945.

t. Satuan Pemerintah Daerah yang bersifat khusus atau istimewa seperti dimaksud oleh pasal 18B ayat (1) UUD 1945, diatur dengan undang-undang. Karena kedudukannya yang khusus dan diistimewakan, satuan pemerintahan daerah yang bersifat khusus atau istimewa ini diatur sendiri oleh UUD 1945. Misalnya, status pemerintahan Daerah Istimewa Yogyakarta, Pemerintahan Daerah Otonomi Khusus Nangroe Aceh Darussalam dan Papua, serta pemerintahan Daerah Khusus Ibukota Jakarta. Ketentuan mengenai kekhususan atau keistimewannya itu diatur dengan undang-undang. Oleh karena itu, pemerintahan daerah yang demikian ini peru disebut secara tersendiri sebagai lembaga atau organ yang keberadaanya diakui dan dihormati oleh Negara. 
u. Dewan Perwakilan Rakyat (DPR) yang diatur dalam bab VII UUD 1945 yang berisi pasal 19 sampai dengan pasal 22B.

v. Dewan Perwakilan Daerah (DPD) yang diatur dalam Bab VIIA yang terdiri atas pasal 22C dan Pasal 220.

w. Komisi Penyelenggaraan Pemilu yang diatur dalam Pasal 22E ayat (5) UUD 1945 yang menentukan bahwa pemilihan umum harus diselenggarakan oleh suatu komisi yang bersifat nasional, tetap, dan mandiri. Nama Komisi Pemilihan Umum bukanlah nama yang ditentukan oleh UUD 1945, melainkan oleh Undang-undang.

x. Bank sentral yang disebut eksplisit oleh pasal 23D, yaitu Negara memiliki suatu bank sentral yang susunan, kedudukan, kewenangan, tanggung jawab, dan independenisnya diatur dengan undang-undang. Seperti halnya dengan Komisi Pemilihan Umum UUD 1945 belum menentukan bank sentral yang dimaksud. Memang benar, nama bank sentral sekarang adalah bank Indonesia. Akan tetapi, nama bank Indonesia bukan nama yang ditentukan oleh UUD 1945, melainkan oleh undnag-undang berdasarkan kenyataan yang diwarisi dari sejarah di masa lalu.

y. Badan Pemeriksa Keuangan (BPK) yang diatur tersendiri dalam bab VIIA dengan judul "Badan Pemeriksa Keuangan", dan terdiri atas 3 pasal, yaitu pasal 23E (3 ayat), pasal 23F (2 ayat), Dan pasal 23G (2 ayat).

z. Mahkamah Agung (MA) yang keberadaanya diatur dalam bab IX, pasal 24 dan pasal 24 A UUD 1945.

aa. Mahkamah Konstitusi (MK) yang juga diatur keberadaanya dalam bab 9 pasal 24 dan pasal 24C UUD 1945.

bb. Komisi Yudisial yang juga diatur dalam bab 9, pasal 24B UUD 1945 sebagai auksiliary organ terhadap Mahkamah Agung yang diatur dalam pasal 24 dan pasal 24A UUD 1945.

cc. Tentara Nasional Indonesia (TNI) diatur tersendiri dalam UUD 1945, yaitu dalam bab 12 tentang pertahanan dan keamanan Negara, pada pasal 30 UUD 1945

dd. Angkatan Darat (AD) diatur dalam pasal 10 UUD 1945

ee. Angkatan Laut (AL) diatur dalam pasal 10UUD 1945

ff. Angkatan Udara (AU) diatur dalam pasal 10 UUD 1945

gg. Kepolisian Negara Republik Indonesia (Polri) yang juga diatur dalam Bab XII Pasal 30 UUD 1945. 
hh. Badan-badan lain yang fungsinya terkait dengan kehakiman seperti kejaksaan diatur dalam undang-undang sebagaimana dimaksud oleh pasal 24 ayat (3) UUD 1945 yang berbunyi: Badan-badan lain yang fungsinya berkaitan dengan kekuasaan kehakiman diatur dalam undang-undang ${ }^{6}$.

Diantara lembaga-lembaga Negara yang disebutkan dalam UUD 1945, ada yang dapat dikategorikan sebagai organ utama atau primer (primery constitusional organs), da nada pula yang merupakan organ pendukung atau penunjang (auxiliary state organs). Untuk memahami perbedaan diantara keduannya, lembaga-lembaga Negara tersebut dapat dibedakan dalam tiga ranah (domain) (i) kekuasaan eksekutif atau pelaksana, (ii) kekuasaan legislatif dan fungsi pengawasan, (iii) kekuasaan kehakiman atau fungsi yudisial.

Dalam cabang kekuasaan eksekutif atau pemerintahan Negara ada Presiden dan Wakil presiden yang merupakan satu kesatuan institusi kepresidenan. Dalam bidang kekuasaan kehakiman, meskipun lembaga pelaksana atau pelaku kekuasaan kehakiman itu ada dua, yaitu Mahkamah agung dan Mahkamah konstitusi tetapi disamping keduannya ada pula komisi yudisial sebagai lembaga pengawas martabat, kehormatan, dan perilaku hakim. Kebradaan fungsi Komisi Yudisial ini bersifat penunjang (auxiliary) terhadap cabang kekuasaan kehakiman. Komisi Yudisial bukanlah lembaga penegak hukum (the enforcer of the rule of law) tetapi merupakan lembaga penegak etika kehakiman (the enforcer of the rule of judicial ethics).

\section{PENUTUP}

\subsection{Simpulan}

Kelembagaan suprastruktural dalam kelangka pemerintahan atau otonomi daerah pada suatu wilaayah infrastruktur politik memiliki sebuah bentuk-bentuk organisasi yang sangatlah umum dalam kalangan masyarakat yang dapatlah dibagi dua yaitu kemsyarakatan dan dari partai politik yang sangat berkembang secara structural yang dimana memilki imbas yang sangat signifikan terhadap perubahan dan pembagian kewengan dalam system politik yang terkait dalam system pemerintahan daerah.

\footnotetext{
6 Attamimi Hamis S. Peran Keputusan Presiden Republik Indonesia Dalam Penyelenggaraaan Pemerintahan Negara Studi Analisis Mengenai Keputusan Presiden Yang Berfungsi Pengaturan Dalam Kurun Pelita Ke1 Pelita Ke-IV, Disertasi Doktoral Hukum Tata Negara, Fakultas Pasca Sarjana, Universitas Indonesia, 1991, hlm. 109.
} 
Pergeseran kekuasaan legislative dan eksekutif dalam kerangka otonomi daerah memang sudah terjadi dengan sdinamika kehidupan politik yang tersistem secara structural dan infrastructural yang memilki sebuah kewenangan setiap komopenen lembaga tersbut namun contohnya suatu fungsi penting dan bahkan dianggap utama dari lemabaga perlemen adalah fungsi penting adalah lembaga legislatif yaitu lembaga pembuat undang-undang ataupun lembaga yang menentukan pembuatan hukum tersebut

\subsection{Saran}

Indonesia adalah Negara hukum yang memang pada dasarnya dapatlah diatur dalam sebuah nilai konstitusi hal ini memberikan sebuah gambaran dan aturan kepada lembaga pemerintahan baik pusat maupun daerah sesuai dengan aturan yang sudah ditetapkan namun dengan kehendak dan kebutuhan nilai social dan masyarakat yang begitu dinamis hal ini berimbas kepada bergesernya nilai nilai sebiah demokrasi dan pergeseran kekuasaan legisltaif dan eksekutif, oleh karena itulah kekuasaan legislatif dan eksekutif haruslah sesuai dengan aturan yang sudah ditetapkan namun apabila kehendak nilai demokrasi dan kekuasaan mampu untuk menyeimbangkan maka perubahan out haruslah disesuaikan dengan aturan hukum yang mengaturnya.

\section{DAFTAR PUSTAKA}

Attamimi Hamis S. Peran Keputusan Presiden Republik Indonesia Dalam Penyelenggaraaan Pemerintahan Negara Studi Analisis Mengenai Keputusan Presiden Yang Berfungsi Pengaturan Dalam Kurun Pelita Ke-1 Pelita Ke-IV, Disertasi Doktoral Hukum Tata Negara, Fakultas Pasca Sarjana, Universitas Indonesia, 1991,

Huntington, Samuel.P, Gelombang Demokrasi Ketiga, Pustaka Utama Grafiti, Jakarta, Ivo

D. Duchaecek, Power Maps, Comperative Politics Of Constitions American

Bibilographical Center, Santa Barbara, California, Oxfrod, 1973,

Kelsen, Hans. General Theory of Law and Sate, Harvad Universty, Press, Cambridge,

Suny Ismail. Pergeseran Kekuasaaan Eksekutif, Calindra, Jakarta, 1965,

Soehino, Hukum Tata Negara, Yogyakarta. Liberty, 1991,

Undang-Undang Negara Republik Indonesia Tahun 1945

Undang-Undang Nomor 9 Tahun 2015 Tentang Pemerintahan Daerah 